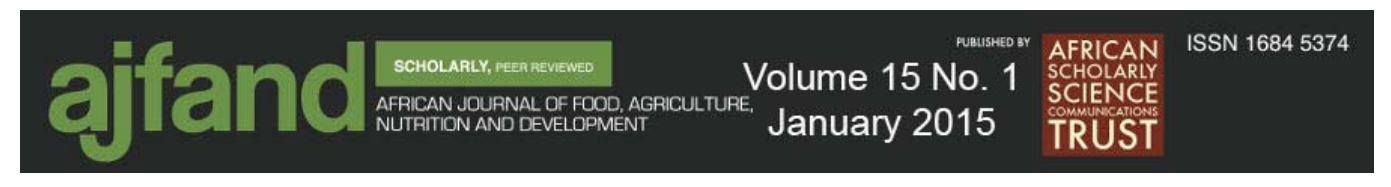

\title{
INTRAHOUSEHOLD ALLOCATION, HOUSEHOLD HEADSHIP AND NUTRITION OF UNDER-FIVES: A STUDY OF WESTERN KENYA
}

\section{Mikalitsa SM ${ }^{1 *}$}

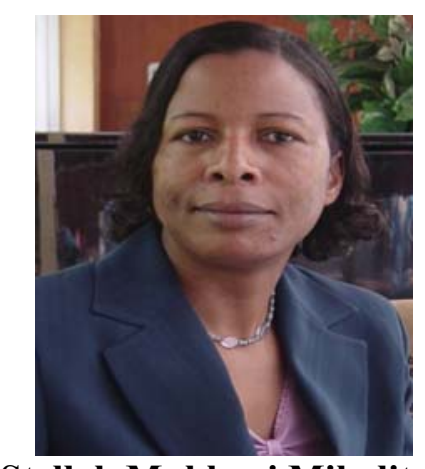

Stellah Mukhovi Mikalitsa

*Corresponding author email: $\underline{\text { smmukhovi@uonbi.ac.ke or smlitsa@yahoo.com }}$

${ }^{1}$ University of Nairobi, Department of Geography and Environmental Studies, P.O. Box 30197-00100, Nairobi, Kenya. 


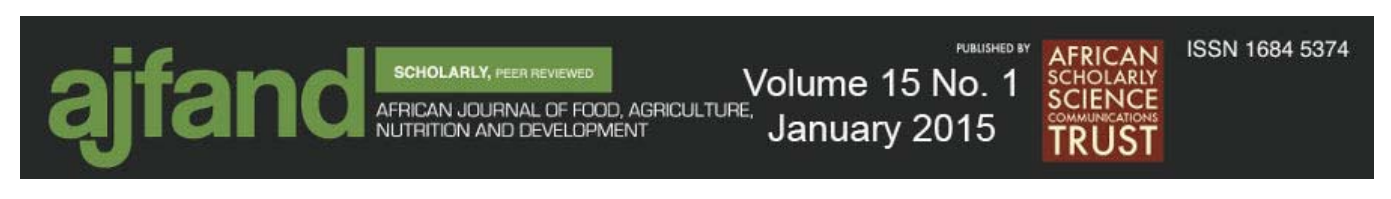

\section{ABSTRACT}

This paper aims to establish whether there is a significant difference in nutritional status of children in male-headed households, de jure female-headed households and de facto female-headed households. The study uses a sample of 199 children aged 6 to 60 months, of mothers in reproductive age, derived from 499 smallholder households in rural Kenya. The sample was selected using multi-stage stratified sampling technique. Three indices namely; height/length-for-age z-scores (stunting), weight-for-age zscores (underweight) and weight-for-height (wasting) z-scores were examined on children in two regions (Vihiga and Busia) in western Kenya. However, for the purpose of testing hypothesis, stunting is used due to its strength in measuring long term effect of food scarcity as compared to wasting and underweight which may vary depending on the period the data is collected (seasonal variation). Two-way (between groups) Analysis of Variance (ANOVA) is used to analyse the height/length-for-age z-scores against household headship. Household headship is stratified according to whether the husband is present and active in decision making (male- headed household), the husband lives away from the household but maintains regular contact with the family including sending remittances (de facto female-headed household), or the woman is recognized as head of household because she is a widow, divorced or separated (de jure female-headed household). Western Kenya is characterized by relatively high levels of undernutrition despite being classified as a region of high agricultural potential. In addition, there is increasing trend of female-headed households in the region hence the need to demonstrate the effect of household headship on nutritional status of the children. The results indicate that household headship has a large and significant effect on stunting of under five children $[\mathrm{F}(1,93)=4.675, \mathrm{p}=.0 .012]$. More boys $(37 \%)$ than girls $(33 \%)$ were stunted and Busia had more children who were stunted $(37 \%)$ than Vihiga $(25 \%)$. The study reaffirms the need to enhance women's control over household resource allocation as one way of enhancing child nutrition in western Kenya.

Key words: Intrahousehold, Nutrition, under-five, Kenya 


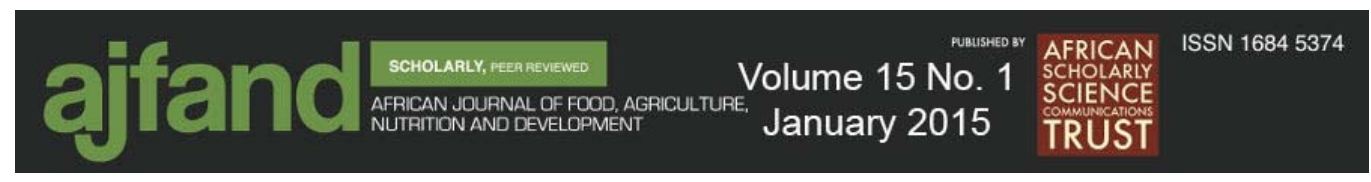

\section{INTRODUCTION}

Malnutrition is a serious problem affecting nearly one third of all pre-school children in developing countries [1]. More than half of child deaths are due to diseases associated with underweight and those who survive into adulthood are more likely to suffer from chronic illness, disability and sometimes reduced physical and intellectual productivity. Even though factors that contribute to under nutrition are many and varied, unsatisfactory food intake and severe and repeated infections are the most important [2]. In Kenya, like in many developing countries, under nutrition affects children in poor households both in rural and urban areas [3]. Smallholder households are amongst the poorest in rural Kenya, hence children born in these households are at the risk of undernutrition [4]. Smallholder farmers operate farms of less than twelve hectares (in Kenya) and are socially, economically and often culturally marginal. They constitute groups with limited or no access to productive resources, technology and credit and have little or no bargaining power at the market.

The smallholder farmers in western Kenya cultivate various crops among them maize, which is the staple, various pulses and horticultural crops. Cash crops are mainly tea in Vihiga and cotton and sugarcane in Busia. Agriculture contributes $35.4 \%$ of household income with limited non- agricultural activities. Other sources of income are smallscale livestock production, small businesses and remittances from relatives. The lack of employment opportunities in the study region has contributed to male labour migration, contributing to many households managed by women. Out- migration also contributes to constraints on labour supply especially during agricultural peak seasons. Due to low agricultural productivity and limited non- agricultural employment, poverty is rampant with $60 \%$ of population in the region living below the rural poverty line [5].

The family structure in Kenya has undergone transformation from predominantly maleheaded households - where the husband is present, key decision maker and bread winner- to an increase in female- headed households [6]. Female-headed households are on the rise especially due to increase in HIV/AIDS as well as male labour migration. This problem is not unique to developing countries: in developed countries, femaleheaded households are also on the increase [7, 8]. Children raised with one parent have different emotional and nutritional challenges as compared to those raised with two parents (mother and father) [9]. While there are different types of female-headed households, in almost all countries, female-headed households are concentrated among the poorer strata of society and often have lower income than male-headed households $[10,11]$. In addition, the absence of male labour through migration and death, leads to serious repercussions on the nutrition of the most vulnerable groups: children, women and the aged. This is attributable to decline in yields and in the shifts in production towards less nutritious crops requiring less labour. It also affects children's access to education through increased reliance on child labour, which, in turn, has further implications not only to the household's future income and welfare but also to the country's human resource development [12]. However, some studies have shown that in female-headed households where women have full control of household income and productive resources, income is used more efficiently and to the advantage of the children $[13,14]$. In other words, not all female-headed households are poor and 


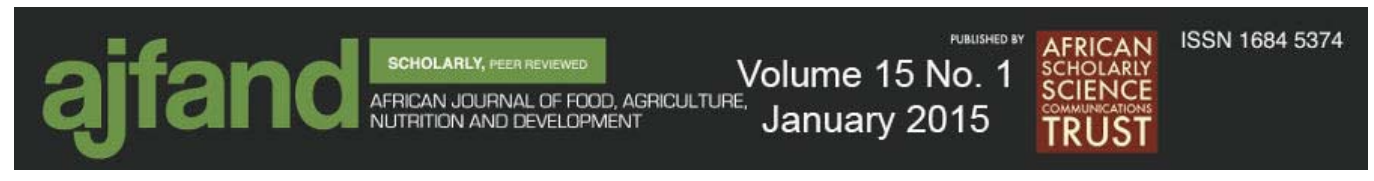

vulnerable, but their state depends on the socio-cultural, economic and policy environment of the region under study. For instance, in Malawi, women access to resources is influenced by socio-cultural setting which varies from one community to the other while in Ghana, institutional framework (policies and legal structures) is important in affecting women and men access to and control over resources $[15,16]$.

The problems of female-headed households in rural areas and the effect of household headship on children's welfare, therefore, vary according to the degree of access to productive resources and the extent to which women are actively involved in decision making within the households. Women may exercise power at household level through making decisions either individually or jointly with their husbands through bargaining and negotiations, and in some extreme situations through coercion. In smallholder households in rural Kenya, the decisions are diverse, including expenditure on food, agricultural production, education, healthcare and other household needs [17]. Studies have shown that even though households which practice commercial agriculture have relatively higher incomes, this does not translate into better nutrition of children [18, 19]. Positive outcome of increased agricultural productivity to the nutrition of children depends on intrahousehold relations and resource allocation. Allocation of resources to increase productivity and improve the health and nutrition of household members might depend on consensus and sometimes conflict between decision makers each with their own goals, priorities and motivations. Empirical evidence has shown that improvements in household food security and nutrition are associated with women's access to income and their role in household decision making on expenditure. This is because women tend to spend a significantly higher proportion of their income than men on food for the family. In Central American countries, for example, when grain grown by men was in short supply, income earned by women from the sale of eggs, cheese, fresh and processed fruit, vegetables and small stock contributed significantly to household provisions [20]. In addition, empirical study in Philippines, observed that in households where women earned higher incomes, there were lower incidences of fever and cholera for pre- school children, while in Rwanda, cash income earned by a woman was positively and significantly associated with improvement in household calorie consumption $[21,22]$.

Even though poverty has been found to be a major factor affecting the wellbeing of children in both poor and rich countries, socio-cultural systems that limit women's access to opportunities and resources are perhaps an important constraint in Kenya. Food insecurity at household level depends on people's entitlements and the sociocultural and legal context that determine who has and who does not have access and control of important productive resources such as land, labour and capital [23]. Access to various assets within the household depends on age, gender and power relations, which in turn, affect ability of individual's food security situation. This could mean that men and women, boys and girls will experience hunger differently. It could also mean that there may be plenty of food within the household but some members of the household may experience undernutrition. Since Kenya is a patriarchal society, the extent to which women will have control over assets such as land is limited, further compromising the nutrition of children under their care. Households have different opportunities or follow different strategies due to differences in factor endowments and 


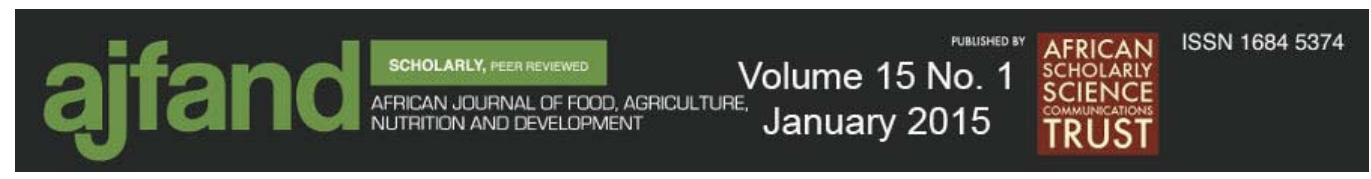

environments, the multiple goals that they have to meet, their perception of the riskiness involved in different enterprises and the social factors that determine intrahousehold relationships [24]. The study deviates from the unitary model as explained by Becker [25]. The unitary model assumes that a household is one harmonious unit where every member has equal access and benefits equally from household assets. Empirical evidence shows that households do not behave according to the unitary type of model [26].

While the effect of intrahousehold allocation on children's wellbeing has received attention from researchers globally, such research in Kenya is scanty. Attempts to meet the Millennium Development Goals (MDGs) especially goal number one of halving the world's poor and hungry people and goal number four of reducing child mortality has given a new impetus towards more research on intrahousehold relations, and how it impedes or speeds up achievement of the goals.

The purpose of the study was to analyse the link between household headship and nutritional status of children under five in western Kenya. The hypothesis tested in this paper is "there is no significant effect of household headship on nutritional status of under-five children".

\section{MATERIALS AND METHODS}

\section{Study Site}

This was a comparative study between two regions; Busia and Vihiga in western Kenya. Busia lies on the Kenyan border with Uganda at latitude $0^{\circ} 1^{\prime}$ 'South and $0^{\circ} 33^{\prime}$ North and at longitude $33^{\circ} 54^{\prime}$ East. On the other hand, Vihiga lies between latitude $0^{\circ}$ and $0^{\circ}$ $15^{\prime}$ North and between longitude $34^{\circ} 30^{\prime}$ East and $35^{\circ} 0^{\prime}$ 'East. The data for this article was collected in 2006-2007, and there was a follow up field visit in 2009. At this time Busia and Vihiga were districts in Western Province. After the promulgation Kenya's new constitution in 2010, the administrative units changed and Busia and Vihiga are now fully fledged counties.

\section{Sampling Procedure}

Given the expansive nature of the study area, a multi- stage stratified random sampling was used. First, western Province was purposively selected out of the eight Provinces in Kenya (before devolved governance structure that created counties). In the second stage, two districts were selected: Busia and Vihiga due to their contrasting socioeconomic, cultural, demographic and ecological characteristics but which suffer from chronic food poverty. In the third stage, five divisions were randomly selected from each district and finally households were selected at the sub location level which is the lowest administrative unit. The households were classified as male-headed, de facto female-headed and de jure female-headed [27]. De facto female-headed units are households where women are heads of households on temporary basis because their husbands are absent due to labour migration but they have ongoing contact, accompanied by the sending home of remittances. De jure female-headed units are households where women live without a male partner on a more or less permanent basis and receive no economic support from a male partner except in the form of child 


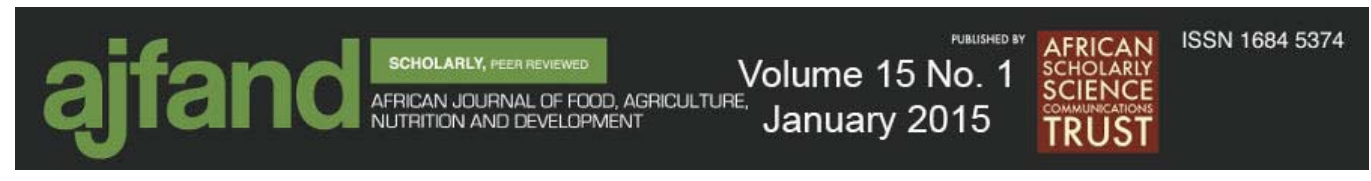

maintenance. Included here are single mothers, divorced women, separated women and widows. A male-headed household is a family unit in which there is an 'intact' couple and the man is the head of the family [28]. In addition, the households were further classified according to technology orientation. There were two categories namely; those who cultivated hybrid maize and those who cultivated seeds saved from the previous harvest. The households were asked to state the expenditure on hybrid maize seed and this formed the basis of grouping the households. The assumption is that if a household cultivates hybrid maize, it also uses other farm inputs such as fertilizers and consequently the output is likely to be higher compared to those farmers who cultivated using farm-saved seeds. High output of maize, which is a food crop as well as a cash crop, could imply higher income for households. Technology is, therefore, a proxy for income variation in households since households that purchase seeds every season are more likely to have higher incomes either from agricultural or non- agricultural activities. A total of 499 households were included in the study and 199 children in these households qualified for analysis of nutritional status. The study sought to test whether the differences in nutritional status of children in different households (male headed, de jure female -headed and de facto female -headed) was significant.

\section{Data Collection and Analysis}

Anthropometric measurements (weights and heights/length) were taken for 199 children between 6 and 60 months, using wooden board (lengths and heights) and a scale (weight). The study was limited to children whose mothers were in reproductive age (15-49 years) and from smallholder households. The children were drawn from male-headed, de jure and de facto female-headed households. In order to measure the nutritional status of children, three indices were examined: height/length-for-age (stunting-HAZ), weight-for-age (underweight-WAZ) and weight-for-height/length (wasting-WHZ). The weight and height/length were recorded on record sheet that had details about the name, age and gender of the child. Children below 2 years who were unable to stand were measured their recumbent length while for those above 2 years, their height was taken while standing in an upright position. Standing height was about $0.7 \mathrm{~cm}$ less than recumbent length. If a child was less than 2 years old and could not lie down, the height was measured and $0.7 \mathrm{~cm}$ added to convert to length [29]. If a child aged 2 years could not stand, recumbent length was taken and $0.7 \mathrm{~cm}$ was subtracted to convert to height. For purposes of weight, the children who were unable to stand on the bathroom scale, the mother's weight was subtracted from total weight of mother and child to obtain the child's weight. The data was collected with the help of a Research Assistant who had been trained on how to use the equipment.

The results were compared with the US National Centre for Health Statistics (NCHS) standards since no comparable Kenyan or African standards have been developed. The NCHS reference population consists of a group of well-nourished children globally and is used as a benchmark. Each of the indicators was expressed in standard deviations (zscores) from median of the reference population. The WHO classification system was used where the cut-off point to identify severely malnourished children is a measurement of -2 Standard Deviations (SD) below the median of the reference group [30]. A z-score of below -3 SD indicated severe conditions of either stunting, 


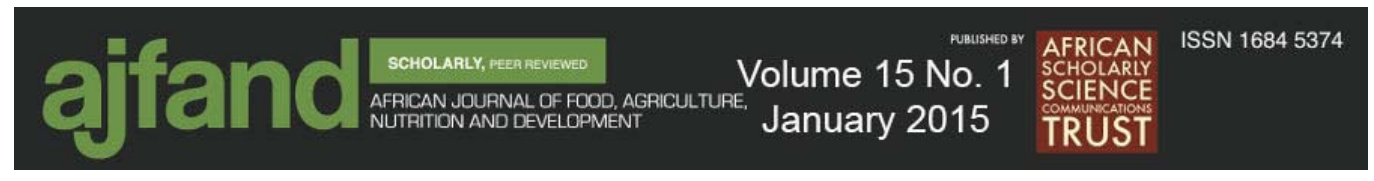

underweight or wasting. Between $-3 \mathrm{SD}$ and $-2 \mathrm{SD}$ was moderate to mild conditions while above -1 SD indicated normal or well-nourished children.

Public domain statistical software for Epidemiology (EPI Info) Version 5 was used for data entry and analysis of anthropometric data. In order to measure the effect of household headship on nutrition, two-way (between groups) Analysis of Variance (ANOVA) was used where the z-scores of height/length-for-age were used as dependent variable and household headship as independent variable.

\section{RESULTS}

\section{Gender of Children and their Nutritional Status}

There was a gender difference in the nutrition of children of the same age. More boys $(37 \%)$ were stunted as compared to $33 \%$ of girls.

\section{Stunting (Chronic undernutrition)}

The study observed that $37 \%$ of the children were stunted in Busia and $25 \%$ in Vihiga (Table1).

\section{Wasting (acute under nutrition)}

The study found that $9 \%$ of children were wasted, $16 \%$ in Busia and $3 \%$ in Vihiga (Table 1).

\section{Underweight cases}

The results showed that $24.7 \%$ of children were underweight. This included $14 \%$ in Busia and $10.7 \%$ in Vihiga (Table 1).

\section{Household Headship and Stunting}

The study observed that children from de facto female -headed households were better nourished than those from de jure female-headed and male-headed households. Two way Analysis of Variance (ANOVA) was conducted to test whether this difference according to headship was significant (Table 2). The results show a statistically significant effect for household headship $[\mathrm{F}(1,93)=4.675, \mathrm{p}=.0 .012]$ and the Eta Squared shows a large effect (Eta Squared=.091). However, technology had no significant effect on stunting (TECH $p=0.318)$. Eta squared in ANOVA measures whether the significant effect of the independent variable (in this case household headship) on the dependent variable (in this case stunting) is large or small (Table 2).

\section{DISCUSSION}

The results of this study show that household headship has a significant effect on child nutrition. Household headship has a bearing on decision making on key aspects of the household such as expenditure, control and access on productive assets. When women have active role in decision making in the household (either as heads of households as co-decision-makers with their husbands), the nutritional status of their children improves. If husbands for the de facto female-headed households have out-migrated to the towns, they are most likely to be employed in non-agricultural sector where the incomes are relatively higher than those in agriculture in Kenya [31]. This consequently 


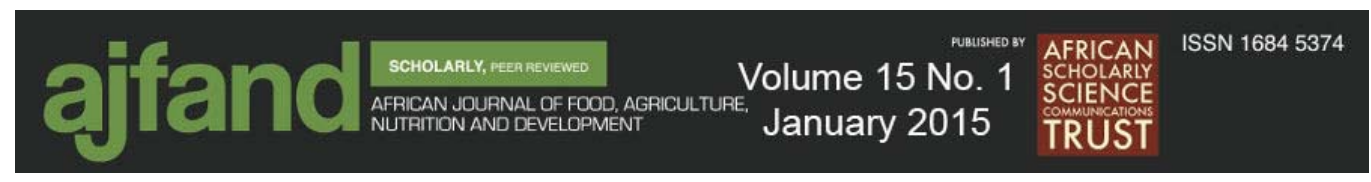

means that the women who remain in the rural areas receive remittances from their husbands in addition to income from agriculture; these women are most likely to have a relatively higher social status than those women whose incomes are entirely derived from agriculture [32]. Enhanced social status of women in de facto households is likely to improve not only their nutritional status but also that of their children. Studies in subSaharan Africa have shown that enhanced social status for women improves prenatal and delivery care for women and feeding practices and immunization of the children [33]. It should be noted, however, that this scenario may not be true for all women in de facto female- headed households in rural Kenya. There are some cases where the husband who has out-migrated may not send any remittances because he may start another family in town [34].

The observation by the current study on the difference in nutrition according to gender has been a subject of study by many scholars. For instance, in Tanzania more boys than girls were found to have better nutrition while in Botswana girls performed better in all nutrition indices of nutrition $[35,36]$. On the contrary, in India, it was observed that boys were favoured in nutrients allocation and other health related investments especially during seasons when food supply was low [37]. While the differences in nutrition according to gender have been attributed to several factors, it is clear that the social and economic value attached to either boys or girls in different societies is important. Studies in Bangladesh, Ethiopia, Indonesia and South Africa show that women's resources within the household though meagre played an important role in household decision making especially in allocation of household expenditure to education and children's clothing and reducing the rate of illness in girls [38]. The better nutritional status for girls could be attributed to the fact that they often accompany their mothers during the daily chores, hence, they are most likely to benefit from additional nurturing and feeding. In addition, the perceived economic value of girls with regard to bride price in some societies could also be another factor contributing to better nourishment as a way of preparing them as future mothers and wives.

Households headed by either female or male have access to and control over a wide range of resources as determined by the culture and institutional frameworks. This may affect the food security and nutrition of its members. De jure female -headed households were the most affected by food poverty and there were higher incidences of malnutrition from these households as compared to male headed and de facto female headed households. This could be attributed to high poverty levels among widows and single mothers whose productive resources could be under the control of male relatives due to the patriarchal systems of the Kenyan society. Children from de facto femaleheaded households were better nourished than those of male- headed households. This compared well with various studies that observed that women spent more of their income on food and care of their children, hence, in households where they had some control over income, there was a likelihood of improved nutritional status of household members especially the children $[39,40]$. Other important factors that affect children's nutrition include: education level of mother, age of child, receipt of information on child feeding, illness and time of introduction of other foods [41]. 


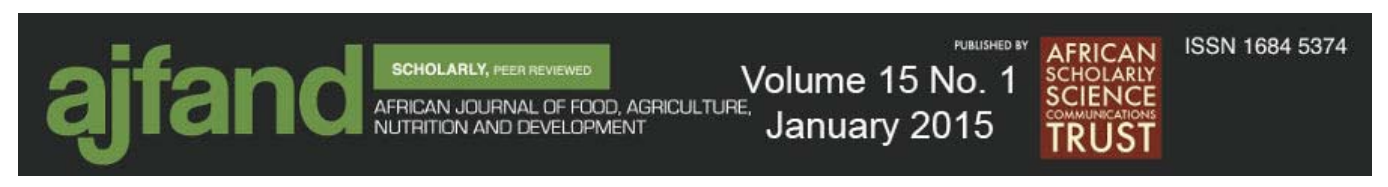

Interestingly, the analysis shows that technology (measured by purchase of hybrid maize seeds) has no significant effect on nutrition status (in this case stunting). Use of technology may imply that a household has potential to produce more food; however, this did not translate into a good nutrition outcome for the children. In this study, better outcome for nutrition of children under five was associated with household headship. Other studies have found that high income in a household did not necessarily translate into better nutrition for children but rather who controlled the income [42]. In households where women were actively involved in decision making, extra income was used to improve the nutritional status of children. What this means in the context of this study, is that, children's nutrition could improve in households where there was high expenditure on hybrid maize, only if women were actively involved in decision making. However, the results of this study differ from those of other studies that have found a significant relationship between household income and child nutrition [43, 44, 45].

\section{CONCLUSION}

The high incidence of stunting in both regions requires various intervention programmes that may include provision of supplementary feeding for children underfive, nutrition awareness campaigns for mothers to adopt appropriate nutrition practices and to better utilize various food stuff grown in the region in order to enhance the nutrition levels of their children. Emphasis should also be put on enhancing the wellbeing of women in various aspects such as decision making at household level, improvement of income, in addition to better access to maternal health.

Increasing trend of female-headed households requires reorientation of the policy environment to address specific constraints that face women's and children's access to important assets and resources that are critical not only for their wellbeing, but also for the adoption of important technologies necessary for enhancing production and incomes. If this is not addressed, the emotional, cognitive and physical development of children raised in vulnerable female-headed households will continue to be compromised. Research is needed with a larger sample to investigate the link between household characteristics and child nutrition in the same area. 


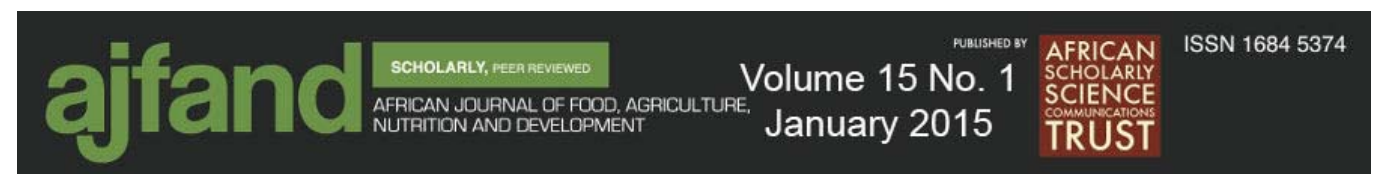

Table 1: Nutritional Status of Children in Busia and Vihiga

\begin{tabular}{|l|l|l|}
\hline Indices & Vihiga & Busia \\
\hline Mean Height $(\mathrm{cm})$ & 82.4 & 81.3 \\
\hline Mean Weight $(\mathrm{kg})$ & 11.2 & 10.5 \\
\hline \% Stunted & 25 & 37 \\
\hline \% Wasted & 3 & 16 \\
\hline \% underweight & 10.7 & 14 \\
\hline Total number of children & $\mathbf{1 1 2}$ & $\mathbf{8 7}$ \\
\hline
\end{tabular}

Source: Household survey data, 2009

Table 2: Two-way ANOVA Results Showing the Role of Technology and Household Headship on Nutrition of Children

Dependent Variable: length/height -for -age Z-score
\begin{tabular}{|l|r|r|r|r|r|r|r|r|}
\hline & $\begin{array}{c}\text { Type III Sum } \\
\text { of Squares }\end{array}$ & $\mathrm{df}$ & $\begin{array}{c}\text { Mean } \\
\text { Square }\end{array}$ & $\mathrm{F}$ & Sig. & $\begin{array}{c}\text { Partial } \\
\text { Eta } \\
\text { Squared }\end{array}$ & $\begin{array}{c}\text { Noncent. } \\
\text { Parameter }\end{array}$ & $\begin{array}{c}\text { Observed } \\
\text { Power }^{2}\end{array}$ \\
\hline Cource & 12.874 & 5 & 2.575 & 2.452 & .039 & .116 & 12.259 & .750 \\
Intercept & 272.323 & 1 & 272.323 & 259.3 & .000 & .736 & 259.299 & 1.000 \\
TECH & 1.060 & 1 & 1.060 & 1.010 & .318 & .011 & 1.010 & .169 \\
HOUSEHOL & 9.820 & 2 & 4.910 & 4.675 & $.012^{*}$ & .091 & 9.350 & .773 \\
TECH *HOUSEHOL & 5.196 & 2 & 2.598 & 2.474 & .090 & .051 & 4.948 & .486 \\
Error & 97.671 & 93 & 1.050 & & & & & \\
Total & 595.000 & 99 & & & & & & \\
Corrected Total & 110.545 & 98 & & & & & & \\
\hline
\end{tabular}

a. Computed using alpha $=.05$

b. $\mathrm{R}$ Squared $=.116$ (Adjusted $\mathrm{R}$ Squared $=.069 \quad$ * significant 0.05 significance level

Source: Household survey data, 2009

\section{ETHICAL CONSIDERATIONS}

This study involved human subjects, hence, effort was made to uphold the wellbeing, values and dignity of the respondents. Various underlying ethical principles were followed. Such principles included; formal approval from relevant authorities, informed consent of respondents and confidentiality of information provided. In addition, only children whose mothers were present were involved in the study. 


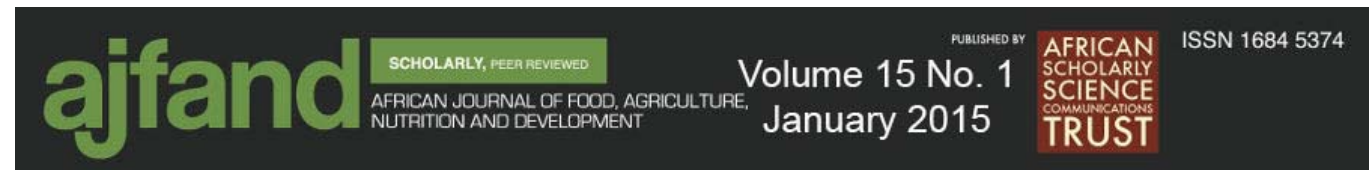

\section{REFERENCES}

1. Rosegrant MW, Ringler C, Benson T, Diao X, Resnick D, Thurlow J, Torero $M$ and $\mathbf{D}$ Orden Agriculture and Achieving the Millennium Development Goals. World Bank (Agriculture \& Rural Development Department). Washington D.C., 2006.

2. Smith L, Ramakrishnan U, Ndiaye A, Haddad $L$ and $\mathbf{R}$ Martorell Importance of Women's Status for Child Nutrition in Developing Countries, Research Report 131, International Food Policy Research Institute, Washington D.C 2003.

3. Klasen S Poverty, Undernutrition, and Child Mortality: Some Inter-Regional Puzzles and their Implications for Research and Policy. J. Econ Inequal, 2008; 6: $89-115$. http://www.link.springer.com/article/10.1007/s10888-007-9056 (Accessed 27/1/2014).

4. Kigutha HN, Van Steveren W and JGAJ Veerman Child Malnutrition in Poor Smallholder Households in Rural Kenya: An In-depth Situation Analysis. Euro. J. of Clin. Nutri. 1995; 49:691-702.

http://www.idpas.org/pdf/2057childmalnutritioninpoorsmallscalehouseholds.pdf (Accessed 27/1/2014).

5. Kenya National Bureau of Statistics. Geographical Dimensions of Wellbeing in Kenya, Who and Where are the Poor? From Districts to Locations: Volume 1. National Bureau of Statistics, Nairobi, Kenya. 2006.

6. Kenya National Bureau of Statistics. Geographical Dimensions of Wellbeing in Kenya, Who and Where are the Poor? From Districts to Locations: Volume 1. National Bureau of Statistics, Nairobi, Kenya. 2006.

7. Angel R and JL Worobey Single Motherhood and Children's Health. J. of Health and Soc Beh., 1988; 29 (1): 38-52. http://www.jstor.org/stable/2137179. (Accessed: 07/06/2010).

8. Brooks-Gunn J and JG Duncan The Effects of Poverty on Children. The Fut. of Child. 1997; 7(2): 55-71. http://www.jstor.org/stable/160238. (Accessed: 07/06/2010).

9. Griffiths $\mathbf{P}$, Mathews $\mathbf{Z}$ and $\mathbf{A}$ Hinde Gender, Family and the Nutritional Status of Children in Three Culturally Contrasting States of India, Soc. Scie. \& Medic.2002; 55 (5): 775-790. http://ww.sciencedirect.com/science/article/pii/50277953601002027 (Accessed 28/1/2014).

10. Lichter DT, McLaughlin DK and DC Ribar Welfare and the Rise in Female-headed Families. The Americ. J. of Socio. 1997; 103 (1):112-143. http://www.jstor.org/stable/2782800. (Accessed: 07/06/2010).

11. Panda PK Female Headship, Poverty and Child Welfare: A Study of Rural Orissa. Econ. and Poli. Weekly, 1997; 32 (43):WS73-WS82. http://www.jstor.org/stable/4406010. (Accessed: 07/06/2010). 


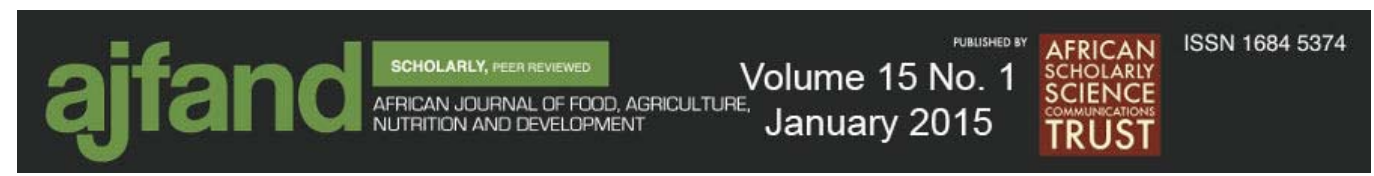

12. Mikalitsa SM Gender-Specific Constraints Affecting Technology Use and Household Food Security in western Province of Kenya. Afric. J. for Food, Agric., Nutr. and Dev., 2010; 10 (4): 2324-2343.

13. Braun JV and G Wiegand-Jahn Income Sources and Income Uses of the Malnourished Poor in Northwest Rwanda In: Braun JV and R Pandya-Lorch (Eds) Income Sources of Malnourished People in Rural Areas: Micro Level Information and Policy Implications. Working Papers on commercialization of Agriculture and Nutrition 5. International Food Policy Research Institute. Washington D.C, 1991.

14. Quisumbing AR and J Malucio Resources at Marriage and Intrahousehold Allocation: Evidence from Bangladesh, Ethiopia, Indonesia and South Africa. Oxford University Press, Oxford, 2003.

15. Kerr RB Food Security in Northern Malawi: Gender, Kinship Relations and Entitlements in Historical Context. J. of S. Afric. Stud. 2005; 31 (1):53-74. http://www.jstor.org/stable/25064972. (Accessed: 16/07/2010).

16. Bacho FZL Can I Sell One of my Cows? Institutions Asset and Gender based Poverty. Ghana J. of Dev. Stud., 2004; 1 (1); 25-48.

17. Edward-Jones G Modelling Farmer Decision-Making: Concepts, Progress and Challenges. Anim. Sci., 2006; 82 (6):783-790.

http://www.journals.cambridge.org/abstracts1357729806000944 (Accessed 29/1/2014).

18. Kennedy ET and B Cogill Income and Nutritional Effects of the Commercialization of Agriculture in Southwestern Kenya, Research Report No. 63. International Food Policy Research Institute, Washington D.C, 1987.

19. Kennedy ET The Effects of Sugarcane Production on Food Security, Health and Nutrition in Kenya: A longitudinal Analysis. Research Report No.78, International Food Policy Research Institute, Washington D.C, 1989.

20. International Food Policy Research Institute Women: The Key to Food Security. International Food Policy Research Institute. Washington D.C, 2000.

21. Garcia M Impact of Female Sources of Income on Food Demand Among Rural Households in Philippines. Quarterly J. of Intern. Agri. 1991; 30 (2):124.

22. Braun JV, De Haen $\mathbf{H}$ and $\mathbf{J}$ Blanken Commercialisation of agriculture under population pressure: Effects on production consumption and nutrition in Rwanda. Research Report no.85. International Food Policy Research Institute. Washington D.C.1991.

23. Misselhorn AA What Drives Food Insecurity in Southern Africa? A MetaAnalysis of Household Economy Studies. Global Environmental Change 2005; 15 (1): 33-43 http://ww.sciencedirect.com/science/article/pii/s0959378004000822 (Accessed 28/1/2014). 


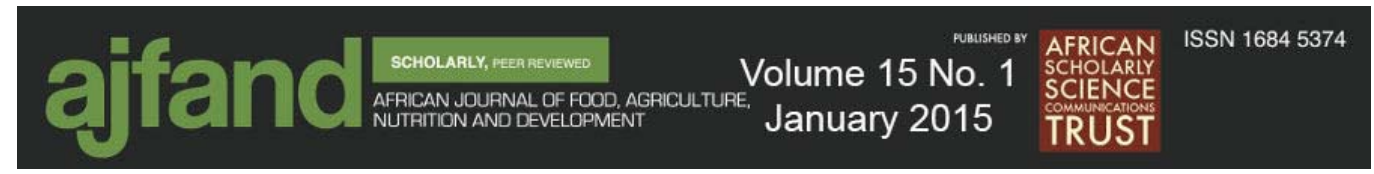

24. Sands DM The Technology Application Gap: Overcoming Constraints to Small-farm Development. FAO Research and Technology Paper No. 1. FAO. Rome. 1986; 5-69.

25. Becker G SA Treatise on the Family, Cambridge: Harvard University Press, 1981.

26. Quisumbing A and B De la Briere Women Assets and Intrahousehold Allocation in Bangladesh: Testing Measure of Power. FCND Discussion Paper 86, International Food Policy Research Institute Washington D.C 2000.

27. Feldstein HS Poats SV and K Cloud Conceptual Framework for Gender Analysis in Farming Systems Research and Extension In: Feldstein, HS and Poats, SV (Eds) Gender and Agriculture: Case Studies in Intra-household Analysis, Kumarian Press 1989; 25-40.

28. Feldstein HS Flora CB and SV Poats The Gender Variable in Agricultural Research, Manuscript Report 225e, IDRC, Ottawa. 1989; 2- 47.

29. United Nations How to Weigh and Measure Children- Assessing the Nutritional Status of Young Children in Household Surveys. UN Department of Technical Cooperation for Development and Statistical Office, New York, 1986.

30. Barrett CB, Buzuneh $\mathbf{M}$ and $\mathbf{A}$ Aboud Income Diversification, Poverty Traps and Policy Shocks in Cote d'ivoire and Kenya. Food Policy 2001; 26 (2001): 367-384 http://www.elsevier.com/locate/foopl (Accessed 28/1/2014).

31. Onyango A, Tucker $\mathbf{K}$ and $\mathbf{T}$ Eisemon Household Headship and Child Nutrition: A Case Study in western Kenya. Soc. Scie \& Medicine 1982; 39 (12):1633-1639.

32. Omilola B Patterns and Trends of Child and Maternal Nutrition Inequalities in Nigeria. Discussion Paper 00968. International Food Policy Research Institute, 2010 .

33. Agesa RU One Family, Two Households: Rural to Urban Migration in Kenya. Rev. of Econ. of the Hous. 2004; 2: 161-178 Kluwer Academic Publishers. Netherlands. http://www.springer.com/static/pdf/40/art (Accessed 28/1/2014).

34. Mbago MC and PP Namfua Some Determinants of Nutritional Status of onto-four-year-old Children in Low Income Urban Areas in Tanzania. J. of Trop. Paediatrics, 1999; 38 (6): 299-306.

35. Salah EOM, Nnyepi $M$ and $\mathbf{T}$ Bandeke Factors Affecting Prevalence of Malnutrition among Children under Three Years of Age in Botswana. Afric. J. for Food, Agric., Nutri. and Dev., 2006; 6 (1): 2-15.

36. Behrman JR Intrahousehold Allocation of Nutrients in Rural India: Are Boys Favored? Do Parents Exhibit Inequality Aversion? Oxford Econ. Papers, New Series, 1988; 40 (1): 32-54, Oxford University Press. http://www.jstor.org/stable/2663253 (Accessed: 05/08/2013). 


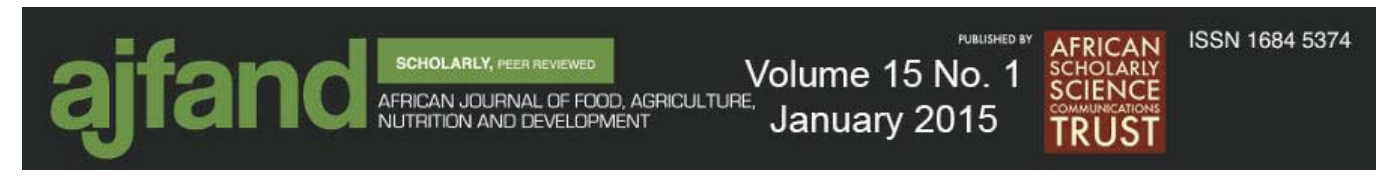

37. Schmidt EM The Effect of Women's Intrahousehold Bargaining Power on Child Health Outcomes in Bangladesh Undergaduate Economic Review, 2012; 9 (1) Article 4: 1-27 Available at: http://digitalcommons.iwu.edu/uer/vol9/iss1/4 (Accessed 12/2/2014).

38. Kumar S Adoption of Hybrid Maize in Zambia: Effects on Gender Roles, Food Consumption and Nutrition. Research Report 100. International Food Policy Research Institute. Washington D.C, 1994.

39. Kennedy E and P Peters Household Food Security and Child Nutrition: the Interaction of Income and Gender of the Household Head, World Development, 1992; 20 (8): 1077-85.

40. Abdulkadir AE, Sohani SA and F Agoi The Dilemma of over-and Under nutrition Coexistence among western Kenya Children. Afric. J. of Food, Agric. and Nutr. Dev., 2009; 9 (4):962-974.

41. Kumar D, Goel NK, Mittal PC and P Misra Influence of Infant-feeding Practices on Nutritional Status of Under-five Children. Indian J. of Paediatrics 2006; 73: 417-418. http://link.springer.com/article/10.1007/BF02758565\#page-1 (Accessed 10/9/2014).

42. Kennedy ET The Effects of Sugarcane Production on Food Security, Health and Nutrition in Kenya: A longitudinal Analysis. Research Report No.78, International Food Policy Research Institute, Washington D.C, 1989.

43. Edris M Assessment of Nutritional Status of Preschool Children of Gumbrit, North west Ethiopia. Ethip.J.Health Dev. 2007; 21 (2):125-129.

44. Amosu AM, Degun AM, Atulomah NOS and MF Olonrewju A study of Nutritional Status of Under-5 Children of Low-income Earners in a Southwestern Nigerian Community. Curr. Res. J. of Biol. Sc. 2011; 3 (6):578-585.

45. Akorede QJ and OM Abiola Assessment of Nutritional Status of Under five Children in Akure South Local Government, Ondo State Nigeria. IJRRAS 2013; 14 (3): 14-24. 